\title{
An Analysis of Types of Taboo Words in Parker Movie
}

\author{
Yunita Permata Sari \\ English Department, Faculty of Social Science and Humanities \\ Putera Batam University \\ Email: qiranmiski3005@gmail.com \\ Batam, Kepulauan Riau, Indonesia
}

\begin{abstract}
This research focuses on types of taboo words that used in Parker movie. This research is a qualitative research. The data of this research were taken from Parker movie. Data were collected by using an observation method and non- participant technique (Sudaryanto,2015). The data are analyzed using the pragmatic identity method (Sudaryanto, 2015). In analyzing the data, the researchers applying Battistella (2005) theory. The result of this research was presented using an informal method.The researcher found out three types of taboo word that appeared in Parker Movie. There are obscenity types, profanity types, and epithet types. Obscenity is the type with the highest number of occurrences, followed profanity type after that. Then, the least number of occurences is epithet type.
\end{abstract}

Key words: Taboo words, Parker movie, type

\begin{abstract}
Abstrak
Penelitian ini berfokus pada jenis kata-kata tabu yang digunakan dalam film Parker. Penelitian ini adalah penelitian kualitatif. Data penelitian ini diambil dari film Parker. Data dikumpulkan dengan menggunakan metode observasi dan teknik non-partisipan (Sudaryanto, 2015). Data dianalisis menggunakan metode identitas pragmatis (Sudaryanto, 2015). Dalam menganalisis data, peneliti menerapkan teori Battistella (2005). Hasil penelitian ini disajikan dengan menggunakan metode informal. Peneliti menemukan tiga jenis kata tabu yang muncul dalam Film Parker. Ada jenis kecabulan, jenis julukan, dan jenis senonoh. Obscenity adalah tipe dengan jumlah kejadian terbanyak, yaitu 62 kali. mengikuti tipe senonoh setelah itu. Kemudian, tipe terakhir adalah tipe vulgar.
\end{abstract}

Kata kunci: Kata- kata taboo, film Parker, jenis

\section{INTRODUCTION}

Language is a means of people to convey idea, opinion, and to express their feeling. In certain situations, every people has different ways to express their feeling. They used language which contained a word that has strong impact on others. For instance, people use language to express anger, upset, or disgusting feeling. When they feel anger, sometimes they don't care good or bad word that they used. People also ignore the situation at that time. As Suryani (2019, p. 77-78) stated that "sometimes they don't care about the way they use their language. They don't pay attention 
to whom they speak and what the best choice of word used". It means that people ignore what word they used, good or bad word in their language. One of the words that they used is taboo word.

Taboo word can bring strong impact on others. It because of taboo words related to bad language that has rude meaning. In expressing bad feelings, people like to utter taboo word that bring shocking effect on others.

In used language, different societies have different kinds of word. Taboo word is one of word that used by people. In certain situations, taboo words is a word cannot be used in. It because taboo words are related to bad language. According to Trudgill (2000), taboo is associated with things which are not said, and in particular with words and expressions which are not used. It means that taboo word related to the words that not used in all situation. In other words, taboo word usually used by people in informal circumtances. It because the taboo word have rude meaning that has strong impact. It can make people who heard that feel shame or even feel insulted.

Yule (2010) stated taboo terms are words and phrase that people avoid for reasons related to religion, politeness and prohibited behavior. It describes people use taboo words in certain situasions, but not in formal situations. Because taboo words will bring embarrassment and offensiveness, some people use taboo words only when they want to express their bad feeling such as anger, disappointment, and dissatisfaction. But, it means that, it can break social value. As Allan \& Burridge (2006) stated that offensiveness is never an intrinsic quality of a word, and the choice between alternative expressions will always depend on context. In other words, people utter taboo words only in appropriate time and place.

There are several journals related to the taboo word topic as references in this study. First, the journals written by Rahmayani \& Fitrawati (2018) entiteld Analysis Types and Functions of Taboo Words in "The wolf of wall street" Movie. Second, the journal written by Kusumaningsih (2019) entitled Taboo Words in 21 Jump Street Movie. Third, the journals written by Qanbar (2011) entitled A sociolinguistic study of the linguistic taboos in the yemeni society. Fourth, the journals written by Gao (2013) entitled A sociolinguistic study of english taboo language. Fifth, the journal written by Gayatri (2017) entitled Taboo Words in Borat Movie. Sixth, the journal written by Pratama (2016) entitled Taboo words and their translation in subtitling: a case study in "the help". Seventh, the journal written by Fajri \& Syarif (2018) entitled The comparison of taboo words and swearwords used by men and women of suku anak dalam in desa balai rajo. Eighth, the journal written by Tajgozari \& Sahragard (2018) entitled Iranian adult speakers' perceptions toward linguistic taboos and euphemisms in iranian society: a sociolinguistic view.

The phenomenon of using taboo words is also found in a movie. In this research, the researcher aims to investigated types of taboo words in Parker movie. It because Parker movie is a movie which filled of the violences, such as in words that uttered by characters.

\section{Types of taboo words}

There are four types of taboo words according to Battistella (2005). There are epithet, profanity, vugarity and obscenity.

\section{a. Ephitet}

Epithet is word or an expression that contain by existence several types of slurs, such as racial slurs, ethnic slurs, gender slurs, and sexual slurs. Some word that belong to this type are bitch, motherfucker, tit- man, etc. 
b. Profanity

Profanity related to the word that related to the religious term or expressions in secular way with aiming to vilify God or anything that associated with religion. In line with Battistella (2005), he stated that "profanity is religious cursing.

\section{c. Vulgarity}

Vulgarity type is a word or expression that relate to the sexual anatomy and excretory function in a rough manner. It is related to the language that often used by a person who under-educated or lower class.

\section{d. Obscenity}

Obscenity refers to the words that are prohibited from public use. It because considered as lack of morality or abhorrent to morrality since mentions scatological references to the body or bodly function or sexual activity which can generate disgusting senses.

\section{METHOD}

This research is qualitative research. As Sugiyono (2019) stated qualitative research is often called as naturalistic research methods because the research is conducted in natural conditions and because the data collected and data analysis are more qualitative in nature. There are many aspects in this research, as follows:

\section{Data Source}

The data of this research were taken from the utterances that uttered by character in Parker movie script. The researcher was downloaded the script from

https://www.scripts.com/script/parker_15613

. Parker movie is American action movie released in 2013. Parker movie directed by Taylor Hackford and written by John J. McLaughing. This movie was choosen because filled of the violences in words that uttered by characters.

\section{Method and Technique of Collecting Data}

In collecting data, the researcher observed the Parker movie script used observation method by Sudaryanto (2015). The technique that used by researcher in collecting data is nonparticipatory technique because the researcher was not involved in the conversation. Then, the researcher classified the selecting dialogues that containing taboo words.

\section{Method and Technique of Analyzing Data}

The researcher used pragmatic identity method in analyzing data. According to Sudaryanto (2015) pragmatic identity method is a method of analyzing the use of language based on the context. For the technique of data analysis, the researcher using the basic technique: dividing key factors technique. Sudaryanto (2015) stated the basic technique: dividing key factors technique is the mental nature of the researchers.

\section{Method and Technique of Presenting Data}

In this research, the researcher used informal method by Sudaryanto (2015). The researcher presented the data analysis explains by words and sentences.

\section{FINDINGS AND DISCUSSION}

Taboo word is a word that used by people to express their feeling in certain circumtance. Based on the data analysis, the researcher found only three types of taboo words that uttered by character in Parker movie based on Battistella (2005) theory. There are obscenity, profanity, and profanity. Obscenity is the highest 
number of occurences, followed by profanity. The last type is epithet type.

\section{a. Obscenity}

Data 1

Hardwicke : What fucking idiot fires a shotgun in a car?

Melander : Shut up, Hardwick!

Hardwicke : My God!

The utterances above occurred in the car when Hardwicke, Melander, Ross, Carlson and Parker managed to rob money at the Ohio State Fair. On the way, the four of them betrayed and wanted to seize the robbery of Parker's share. On Melander's instructions, Ross tried to shoot Parker. But failed, because Parker tried to save himself. So that makes their cars lose control and almost harm them all.

In data 1 , there is the taboo word "fuck" that uttered by Hardwicke. This word refers to obscenity type. The taboo word "fuck" here is an expression that adrdressed to Ross. By uttering the taboo word "fuck", Hardwicke express his disgust feeling toward Ross.

Data 2

Parker : First, I should tell you myself personally. I always follow through. Always.

Bobby : Fuck you!

Parker : You gonna tell me what I need to know, or I'm gonna press down on this chair until it crushes your trachea.

The utterances above took place at Bobby's club, Hardwicke's brother. Parker came to ask where Hardwicke was. However, Bobby did not want to say it. So that makes Parker angry and beat Bobby. In data 2, it can bee seen the taboo word "fuck" in Bobby utterance. The taboo word "fuck" refers to obscenity type. Here, the taboo word "fuck" doesn't mean to have sexual intercourse but addressed to Parker as an disgust expression. By utters the taboo word "fuck", Bobby express his repulsion feeling toward Parker.

a. Profanity

Data 3

Parker : It's small but it hurts.

Jack : He knows we're wearing vests, he'll shoot you in the face. Now can we just get this over with so I can go to goddamn hospital?

Parker : Ok, Oliver. Put Jack into the other room.

The utterances above happened at Jack and Oliver's place when Parker wanted to rob their money. Previously, he injured Jack's leg by shooting him in the parking area. Then, he instructs Jack to pretend that he has been saved by him to his friend Oliver. So Oliver was fooled. Parker quickly pointed his gun at Oliver. Jack told Oliver, if Parker knew they were wearing vests and would shoot him in the face.

In data 3 , there is the taboo word "goddamn" in Jack's utterace. This word refers to the profanity type. It because the taboo word "goddamn" is related to the religious term that refers to the Jesus Christ and usually used in the church. Jack exprees his feeling toward Parker by utters a taboo word "goddamn" where is outside the formal occasion.

Data 4

Melander : Why the hell did you bring her in here?

Hardwicke : Cos she was peeking through the fucking window

The utterances above happened in the hideout of Melander and his friend, after they robbed millions of dollars of jewelry by Miriam Hugh Clinton, a socialite woman. Unexpectedly, Hardwicke saw Leslie, who was spying on them when they counted the robbery. He caught and brought Leslie into the house. 
In data 4 , there is the taboo word "hell" that uttered by Melander. This word refers to the profanity type. It because the taboo word "hell" is related with religious term that has correlation with a bad and dirty place for human who are live without following the God's rule in the beyond. By uttering a taboo word "hell", he express his unlike feeling towards the existence Leslie.

b. Epithet

Data 5

Parker : Someone gets hurt, the cops come after us. That's the big fucking deal!

Hardwicke : Motherfucker!

Parker : I said behind the livestock pavilion.

The utterances above took place in a warehouse where they gathered and moved the money from the robbery. Parker was very angry toward Hardwicke and hit him. Because Hardwicke did not follow Parker's instructions to burn straw behind the livestock pavilion, but behind the dancing stage. So it hurts someone.

In data 5, there is the taboo word "motherfucker" in Hardwicke's utteraces. This word refers to the epithet type. Hardwicke express his feeling toward Parker by utters a taboo word "motherfucker". The taboo word "motherfucker" is related to the sexual slurs. Hardwicke utters the taboo word "motherfucker" to insult Parker.

Data 6

Carlson : Let me see what you got.

Bitch!I'm gonna fuck you and then you die!

Leslie : In your dreams you fat, ugly fuck!

The utterances above happened when Leslie was held hostage by Melander and his friend. Carlson tried to act indecent towards her. So she tried to fight by spitting on his face.
In data 6 , it can be seen the taboo word "bitch" that uttered by Carlson. The taboo word "fuck" refers to the epithet type. Carlson express his anger towards Leslie by utters a taboo word "bitch". The taboo word "bitch" is related to the gender slurs. Carlson called leslie by using the taboo word "bitch" which mean female dog.

\section{CONCLUSION}

Based on the analysis, the researcher has come to the conclusion. The taboo word is a phenomena that involve in used language in societies. The use of taboo words can also be found in utterances by the character of a movie, such as in Parker movie. It can be seen, there are three types of taboo words that used by characters in Parker movie. There are obscenity types, epithet types, and profanity types.

Based on the conclusion above, the researcher has some suggestions to the next researcher who interested to conduct same topic. First, there are other theories that can apply in conducting taboo word topic aside from Battistella (2005) Second, there are other source that can be analyzed such as song lyrics and novel.

\section{REFERENCES}

Battistella, E. L. (2005). Bad language: Are some words better than others. New York: Oxford University Press.

Fajri, M., \& Syarif, H. (2018). The comparison of taboo words and swearwords used by men and women of suku anak dalam in desa balai rajo. E- Journal of English Language \& Literature, 7(4).

Gao, C. (2013). A sociolinguistic study of english taboo language. Theory and Practice in Language Studies, 3(12), 2310-2314. https://doi.org/10.4304/tpls.3.12.231 


\section{$0-2314$}

Gayatri, D. A. S. C. (2017). Taboo Words in Borat Movie. Jurnal Humanis, 20, 217-224.

Keith, Allan \& Burridge, K. (2006). Forbidden words. UK: New York: Cambridge University Press.

Kusumaningsih, D. G. Y. (2019). Taboo words in 21 jump street movie. Retorika: Jurnal Ilmu Bahasa, 5(1), 23-31.

Pratama, A. D. Y. (2016). Taboo words and their translation in subtitling: a case study in "the help." Retorika: Jurnal Ilmu Bahasa, 2(2), 350-363. https://doi.org/10.22225/jr.2.2.362.3 50-363. TABOO

Qanbar, N. (2011). A sociolinguistic study of the linguistic taboos in the yemeni society. Modern Journal of Applied Linguitics.

Rahmayani, D. P., \& Fitrawati. (2018). Analysis types and functions of taboo words in "The wolf of wall street" movie. E- English Language \& LiteratureEnglish Language \& Literature, 7(3).

Sudaryanto. (2015). Metode dan Aneka Teknik Analisis Bahasa. Yogyakarta: Duta Wacana University Press.

Sugiyono. (2019). Metode penelitian kuantitative, kualitatif dan $r \& d$. Bandung: Alfabeta.

Suryani, M. S. (2019). Impolite responsive to Donald Trump 's posts on instagram. Journal IdeBahasa, 1(1), 77-78.
Tajgozari, M., \& Sahragard, R. (2018). Iranian adult speakers' perceptions toward linguistic taboos and euphemisms in iranian society: a sociolinguistic view. Journal of Language Art. https://doi.org/10.22046/LA.2018.2 1

Trudgill, P. (2000). Sosiolinguistic: an introduction to language and society. (D. Crystal, Ed.) (4th ed.). London, England: Penguin Books.

Yule, G. (2010). The study of language ((4th ed.)). NY, USA: Cambridge University Press. 